\title{
In vitro Propagation of Four Grape Cultivars
}

\section{Mostafa, F. M.A.; M. M. Shaaban ; Doaa S. Elazab and M.T. Kamel}

Pomology Dept., Fac. Agric., Assiut University, Assiut, Egypt

Email: Farouk.mostafa@agr.au.edu.eg

\begin{abstract}
:
Successful propagation of in vitro four grape cvs. (Concord, Thompson Seedless, Beauty Seedless and King Ruby) through shoot tips and nodal cuttings was established. The best explants sterilization was achieved with $10 \%$ cholorox for 10 minutes. The combination of $1.0 \mathrm{mg} / \mathrm{L} \mathrm{BA}$ and $0.01 \mathrm{mg} / \mathrm{L}$ NAA produced the maximum sprouting rate $(100,91.7,100,83.3 \%)$ and the least number of days for buds sprouting $(6,9,5$ and 11) of Concord, Thompson Seedless, Beauty Seedless and king Ruby cultivars, respectively. Additionally, the same medium induced the greatest average of shoots number/explants $(5.50,4.95,5.27$ and 4.69) and the highest shoot length $(5.3,5.2,5.2$ and $4.9 \mathrm{~cm})$ for the four tested grape cvs. The third subculture induced the maximum response of sprouting frequency and the optimum average of shoot numbers/explants for the four examined cultivars. For rooting of in vitro shoots, Half strength MS medium supplied with $1.0 \mathrm{mg} / \mathrm{L}$ IBA resulted in the best root formation $(90,100,80$ and $70 \%)$ for Concord, Thompson Seedless, Beauty Seedless and King ruby cultivars, respectively.
\end{abstract}

Key words: in vitro propagation, grape cvs., shoot tips, nodal segments

Received on: 22/10/2015

Accepted for publication on: 29/10/2015

Referees: Prof. Hassan A. Abdel-Galil Prof. Moawad A. Mohamed 


\section{Introduction:}

Grapevine (Vitis spp.) is considered to be one of the most important horticulture fruit crop in the world. Grape in Egypt has a great importance for the economy, especially for high quality cultivars with early production for export. The amount of Egypt's exports of grapes represented an average of $2.58 \%$ from the total exported quantity of the fruits during the period from 2005 to 2009 . Moreover, grapes are being usually propagated by stem cuttings and occasionally by layering and grafting. Propagation by traditional methods is slow process and cannot assist in development of new genotypes with desired traits. The application of modern biotechnological methods such as micropropagation have been approved to be a powerful complement to traditional methods; it is mainly used to promote rapid mass propagation, enhance the economic value of the desired genotypes guarantee the production of healthy and true to type mother plants (Bouquet and Torregrosa 2003). Micropropagation appears to be a potential method of plant regeneration systems through embryogenesis and organogenesis. Thus it is necessary to optimize micropropagation procedure to facilitate in vitro regeneration for genetic engineering techniques with focus on plant growth regulators which have a significant role on growth and development of in vitro propagation of grapevine that in turn determine the best cytokinin type, concentration and the maximum number of subcultures is very critical for in vitro mass production.
Therefore, the aim of the present study was to develop a successful micropropagtion protocol for some grape cvs. including the evaluation of some growth regulators on culture establishment, multiplication and rooting and also to determine the maximum number of subcultures that maintain the propagation potential of the cultures without effect on the frequency and the quality of the propagation system. Furthermore, these experiments were conducted to realize the final objectives of this study to produce genetically engineered grapevines for tolerance to high temperatures.

\section{Materials and Methods:}

Micropropagation of grapevines

Initiation of aseptic culture: Four grape cultivars, namely: Concord (Vitis lubrasca), Thompson seedless, Beauty seedless, and King ruby (Vitis vinifera) were used for this study. Nodal segments and shoot tips were collected from the greenhouse and dissected to remove leaves or tendrils and cut into pieces about $1-2 \mathrm{~cm}$ in length to prepare for surface sterilizing in order to obtain clean cultures. Explants were washed under running tap water with liquid soap solution for one hour followed by soaking in $70 \%$ ethyl alcohol for 3 minutes. After several rinses with distilled water, explants were treated with $5 \%$ or $10 \%(\mathrm{v} / \mathrm{v})$ commercial bleach (cholorox) solution with two drops of tween 20 (a wetting agent, polyoxyethylene sorption monolaurate) for 5, 10 and 15 minutes under a laminar air flow-hood. Finally explants were rinsed three to four times with sterile distilled water for $5 \mathrm{~min}$ each. 
Culture establishment: In this experiment, explants were inoculated on MS medium which was used for propagation. MS medium was recommended for grapes micropropagation according to previous reports (Dzazio et al.; 2002; sajid and Anwar; 2006; Nookarago et al. 2008; ElAgamy et al. 2008). Murashige and Skoog (1962) medium was fortified with two types of cytokinins (BA and Kin) at concentrations 1.0 or 2.0 $\mathrm{mg} / \mathrm{L}$ individually or in combination with NAA at $0.01 \mathrm{mg} / \mathrm{L}$.

The following growth parameters were measured:

1 - Sprouting percentage $(\%)$.

2- Days to sprout.

3- Mean number of shoots/explants.

4- Length $(\mathrm{cm})$ of the main shoots.

Multiplication of shoots: The new obtained shoots that grew into plantlets 4 weeks later were cut to obtain new nodal sections which were then transferred to MS fresh medium containing $1.0 \mathrm{mg} / \mathrm{L}$ BA and 0.01 $\mathrm{mg} / \mathrm{L}$ NAA for shoot multiplication. Plantlets were sub cultured every 30 days. Five cycles were conducted to determine the best subculture that produced the maximum propagation rate $(\%)$.

Rooting of shoots: Elongated shoots were cultured in full or half strength MS medium supplemented with IBA at the following concentrations $(1.0,2.0,3.0 \mathrm{mg} / \mathrm{L})$ in order to study their rooting capacity (\%). Totally 6 media were used (R1: 1.0 $\mathrm{mg} / \mathrm{L} \mathrm{IBA}+1 / 2 \mathrm{MS}$; R2: $2.0 \mathrm{mg} / \mathrm{L}$ IBA + 1/2 MS; R3: $3.0 \mathrm{mg} / \mathrm{L}$ IBA + 1/2 IBA; R4:1.0 mg/L IBA+ MS;
R5:2.0 mg/L IBA + MS and R6: 3.0 $\mathrm{mg} / \mathrm{L} \mathrm{IBA}+\mathrm{MS}$ )

Surface sterilized explants were cultured vertically on Majenta boxes, containing $50 \mathrm{ml}$ of Murashige and skoog (MS) medium supplemented with $30 \mathrm{~g} / \mathrm{L}$ sucrose and $2.4 \mathrm{~g} / \mathrm{L}$ gelrite. The $\mathrm{pH}$ of the media was adjusted to 5.7 with $1 \mathrm{~N} \mathrm{NAOH}$ or $1 \mathrm{~N}$ $\mathrm{KOH}$ before adding the agar. Media were autoclaved for $20 \mathrm{~min}$ at a pressure of $1.1 \mathrm{~kg} / \mathrm{cm}^{2}$ and $121^{\circ} \mathrm{C}$. Growth regulators were filter sterilized and added to the medium after autoclaving and cooling at $55^{\circ} \mathrm{C}$.

All cultures were incubated in a controlled climate chamber at $26 \pm 1^{\circ} \mathrm{C}$ in $16 / 8 \mathrm{~h} \mathrm{light/dark}$ photoperiod with $\left(80 \mu \mathrm{mol} \mathrm{m} \mathrm{m}^{-2} \mathrm{~s}^{-1}\right)$ light intensity provided by cool white fluorescent tubes.

\section{Statistical analysis:}

For experimental data analysis, factorial experiment in a randomized complete block design (RCBD). Means were compared using the Least Significant Differences (LSD) test at 5\% level of probability according to Gomez and Gomez (1984).

Results and Discussion:

Initiation of aseptic culture:

Obtaining clean cultures is a prerequisite for successful tissue cultures techniques. To solve the problem of contamination, two concentrations of chlorox (5 and 10\%) for different periods (5, 10 and $15 \mathrm{~min}$ ) were applied to the explants in table (1). The obtained results indicated that the concentration of $10 \%$ chlorox was superior to $5 \%$ chlorox in preventing contamination. Chlorox $(10 \%)$ treatment resulted in 60,100 and $100 \%$ clean cultures for 5, 10 and 15 minutes, respectively, while chlorox $(5 \%)$ treatment recorded 50 , 
70 and $80 \%$ uncontaminated explants for 5,10 and 15 minutes, respectively, without significant differences between both of them. Although chlorox $(10 \%)$ treatment for both 10 and 15 minutes was effective in contamination inhibition, 15 minutes treatment duration caused higher browning (20\%) to the cultured tissue than 10 minutes treatment $(5 \%$ browning). In a similar study Jaskani et al. (2008) reported that the disin- festations treatment of explants of grape CV. Perlette with chlorox $(10 \%)$ for 15 minutes was the most suitable to get high aseptic cultures (96.3\%). Alizadeh et al. (2010) found that the combination of $0.1 \% \mathrm{HgCl} 2$ for $7 \mathrm{~min}$, followed by $70 \%$ ethyl alcohol for $5 \mathrm{sec}$ was the best treatment for surface sterilization of grape explants, while treatment duration over 7 min. caused explants necrosis.

Table (1): Effect of cholorox (5\% and 10\%) and different treatment periods on sterilization (\%).

\begin{tabular}{|c|c|c|c|c|c|c|c|c|}
\hline \multirow{2}{*}{ Treatment } & \multicolumn{4}{|c|}{ Cholorox (5\%) } & \multicolumn{4}{|c|}{ Cholorox (10\%) } \\
\hline & $5 \mathrm{~min}$ & $10 \mathrm{~min}$ & $15 \mathrm{~min}$ & Mean & $5 \mathrm{~min}$ & $10 \mathrm{~min}$ & $15 \mathrm{~min}$ & Mean \\
\hline Clean culture (\%) & 50.00 & 70.00 & 80.00 & 66.60 & 60.00 & 100.00 & 100.00 & 86.60 \\
\hline Contamination (\%) & 50.00 & 30.00 & 20.00 & 33.30 & 40.00 & 0.00 & 0.00 & 13.30 \\
\hline Browning (\%) & 0.00 & 0.00 & 10.00 & 3.33 & 0.00 & 5.00 & 20.00 & 8.30 \\
\hline Mean & 33.30 & 33.30 & 36.60 & & 33.30 & 35.00 & 40.00 & \\
\hline L.S.D. at $5 \%$ & $\begin{array}{l}\text { iods }= \\
\text { action }\end{array}$ & $\begin{array}{l}\text { tures } \\
0.10 \\
.13 \\
\text { N.S }\end{array}$ & & riod $=$ & $\begin{array}{l}\text { ion } \\
.18 \\
3 \\
\text { N.S }\end{array}$ & & $\begin{array}{l}\text { riod }=8 \\
\text { teractio }\end{array}$ & $\begin{array}{l}\text { I.S } \\
8 \\
=12.20\end{array}$ \\
\hline
\end{tabular}

\section{Culture establishment:}

Data recorded in table (2) showed that the sprouting percentage of in vitro explants varied among different cultivars as affected by the cytokinins types and concentrations. All levels of BA and Kin facilitated shoot bud differentiation. For all studied cultivars, culture initiation showed better sprouting frequency when BA alone or in combination with NAA added to MS medium compared to Kin treatments. The combination 1.0 $\mathrm{mg} / \mathrm{L} \mathrm{BA}+0.01 \mathrm{mg} / \mathrm{L}$ NAA produced the highest sprouting rate 100 , 91.66, 100, 83.33\% for Concord, Thompson Seedless, Beauty Seedless and king Ruby, respectively. While, $\mathrm{Kin}$ at $1.0 \mathrm{mg} / \mathrm{L}$ recorded the least sprouting capacity 58.3, 66.6, 58.3,
$50 \%$ for Concord, Thompson Seedless, Beauty Seedless and King Ruby, respectively. The differences between BA and Kin treatments were significant. The addition of NAA alone or with BA enhanced shoot production compared to the presence of only BA in the medium. Moreover, the least number of days required for buds sprouting were achieved at the same media. Beauty seedless cultivar achieved the earliest bud sprouting in 5 days followed by Concord (6) days. The longest duration for bud sprouting was 24 days for King ruby when Kin was added to the media at 2.0 $\mathrm{mg} / \mathrm{L}$ with $0.01 \mathrm{mg} / \mathrm{L}$ NAA. Several publications documented Benzylamino purine as the most effective cytokinin for culture establishment 
(Hu and Wang 1983; Heloir et al., 1997). Similarly to our results, Tapia and Read (1998) documented that BA at 0.5 or $1.0 \mathrm{mg} / \mathrm{L}$ in combination with NAA at $0.01 \mathrm{mg} / \mathrm{L}$ responded the best medium for shoot formation in some grapes hybrids. The best culture establishment for deGrasset rootstock was $2.0 \mathrm{mg} / \mathrm{L}$ BA in MS- 1 medium (Mukherjee et al. 2010). The optimum mean of culture establishment for four different grape genotypes $(59.5 \%)$ with the lowest mean of days to bud sprout (9.22) was obtained when nodal segments were cultured on MS supplied with 2.0 $\mathrm{mg} / \mathrm{L}$ BAP $+0.2 \mathrm{mg} / \mathrm{L}$ NAA (Alizadeh et al. 2010). Kin treatment re- sulted in significant reduction in sprouting rate with irregularly formed shoots. In contrast to these results, (Poudel et al. 2005) found that Kin was the most suitable cytokinin for in vitro propagation of two wild grapes. Whereas the combination of Kinetin with other cytokinins can be useful for culture intition of some genotypes; (Jamwal et al 2013) reported that the addition of $\mathrm{BA}$ at $1.0 \mathrm{mg} / \mathrm{L}$ with $\mathrm{Kin}$ at $1.0 \mathrm{mg} / \mathrm{L}$ to Ms medium produced the maximum culture establishment $(86.66 \%)$ with the lowest days (12) to sprout for Perlette grape cultivar, revealing that the response of grapevine to cytokinins is a genotype dependant.

Table (2): Effect of cytokinins (Benzylaminopurine and Kinetin) and NAA at different concentrations on sprouting rate $(\%)$ and time to bud sprouting in four grape cultivars.

\begin{tabular}{|c|c|c|c|c|c|c|c|c|c|c|}
\hline \multirow[b]{2}{*}{ Treatment $(\mathrm{mg} / \mathrm{L})$} & \multicolumn{5}{|c|}{ Sprouting rate $(\%)$} & \multicolumn{5}{|c|}{ Days from culture to sprout } \\
\hline & 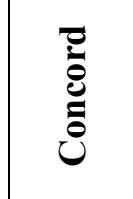 & 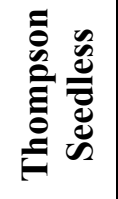 & 党 & 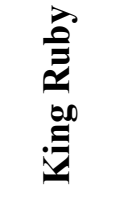 & $\sum_{\Sigma}^{\Xi}$ & 苛 & 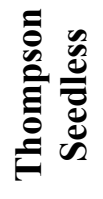 & 导 & 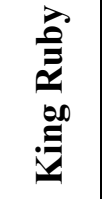 & $\sum^{\tilde{E}}$ \\
\hline 1.0 BA & 87.50 & 83.30 & 95.80 & 75.00 & 85.40 & 10 & 11 & 10 & 13 & 11 \\
\hline $2.0 \mathrm{BA}$ & 95.80 & 87.50 & 87.50 & 79.16 & 87.50 & 13 & 15 & 10 & 12 & 12.50 \\
\hline $1.0 \mathrm{BA}+0.01 \mathrm{NAA}$ & 100.00 & 91.66 & 100 & 83.33 & 93.70 & 6 & 9 & 5 & 11 & 7.80 \\
\hline 2.0 BA + 0.01 NAA & 100.00 & 87.50 & 91.60 & 79.16 & 89.50 & 10 & 13 & 9 & 14 & 11.50 \\
\hline 1.0 Kin & 58.30 & 66.60 & 58.30 & 50.00 & 58.30 & 14 & 16 & 20 & 22 & 18 \\
\hline $2.0 \mathrm{Kin}$ & 62.60 & 70.83 & 50.00 & 54.16 & 59.40 & 18 & 20 & 19 & 19 & 19 \\
\hline 1.0 Kin + 0.01 NAA & 66.60 & 70.83 & 62.50 & 54.16 & 63.50 & 12 & 15 & 17 & 17 & 15.25 \\
\hline 2.0 Kin + 0.01 NAA & 62.60 & 75.00 & 54.16 & 66.60 & 64.50 & 15 & 23 & 20 & 24 & 20.50 \\
\hline Mean & 79.00 & 79.00 & 74.90 & 67.70 & & 12.25 & 15.25 & 13.75 & 16.50 & \\
\hline L.S.D. at $5 \%$ & $\begin{array}{l}\text { Cultiva } \\
\text { Treatm } \\
\text { Interact }\end{array}$ & ion $=$ & & & & & & & & \\
\hline
\end{tabular}

Shoot formation and shoot length on MS medium in response to the different combinations of cytokinins and NAA were also evaluated as represented in table (3). Different growth regulators combinations and concentrations had direct impact on cell division and expansion which on turn affect the shoot length (Gordon et al., 1975). The obtained results revealed that BA induced higher values of shoots number/explant than Kin. For all studied cultivars, MS medium containing $1.0 \mathrm{mg} / \mathrm{L}$ BA and 0.01 
mg/L NAA induced the highest mean number of shoots/explants 5.50 for Concord followed by 4.95 for Thompson Seedless. While, Beauty Seedless produced 5.27 shoot/explants and 4.69 for King Ruby. Moreover, the optimum shoots length 5.30 for Concord; 5.22 for Thompson seedless; 5.25 for Beauty seedless and $4.91 \mathrm{~cm}$ for King Ruby were obtained from the same MS medium. King Ruby produced the lowest significant average of shoot numbers/ explants (3.68) compared to other cultivars. Furthermore, shoots that grew in MS medium containing Kin, had abnormal growth with curly leaves. Aazami (2010) results indi- cated that the maximum mean number of shoots per explants (3.8-5.4) was occurred on MS medium supplied with $1.5 \mathrm{mg} / \mathrm{L} \mathrm{BA}$ and $1.0 \mathrm{mg} / \mathrm{L}$ IBA compared to MS medium containing BA or TDZ alone. Nookaraju et al. (2008) stated that BA alone at 2.22 $\mathrm{MM}$ on MS medium produced the highest number of shoots (8.1/explants) while, the addition of IAA at $1.61 \mathrm{MM}$ to BA showed the maximum shoot height $(4.97 \mathrm{~cm})$ of Crimson seedless grape cultivar. In a further study, shoot elongation was increased when MS medium was fortified with IAA at $1.14 \mathrm{MM}+\mathrm{BA}$ at 2.22 MM compared to BA at 2.22 MM alone (Mhartte et al. 2000).

Table (3): Effect of different concentrations of cytokinins (Benzylaminopurine and Kinten) and NAA on number of shoots/explant and shoot length of the main shoot $(\mathrm{cm})$ in four grape cultivars.

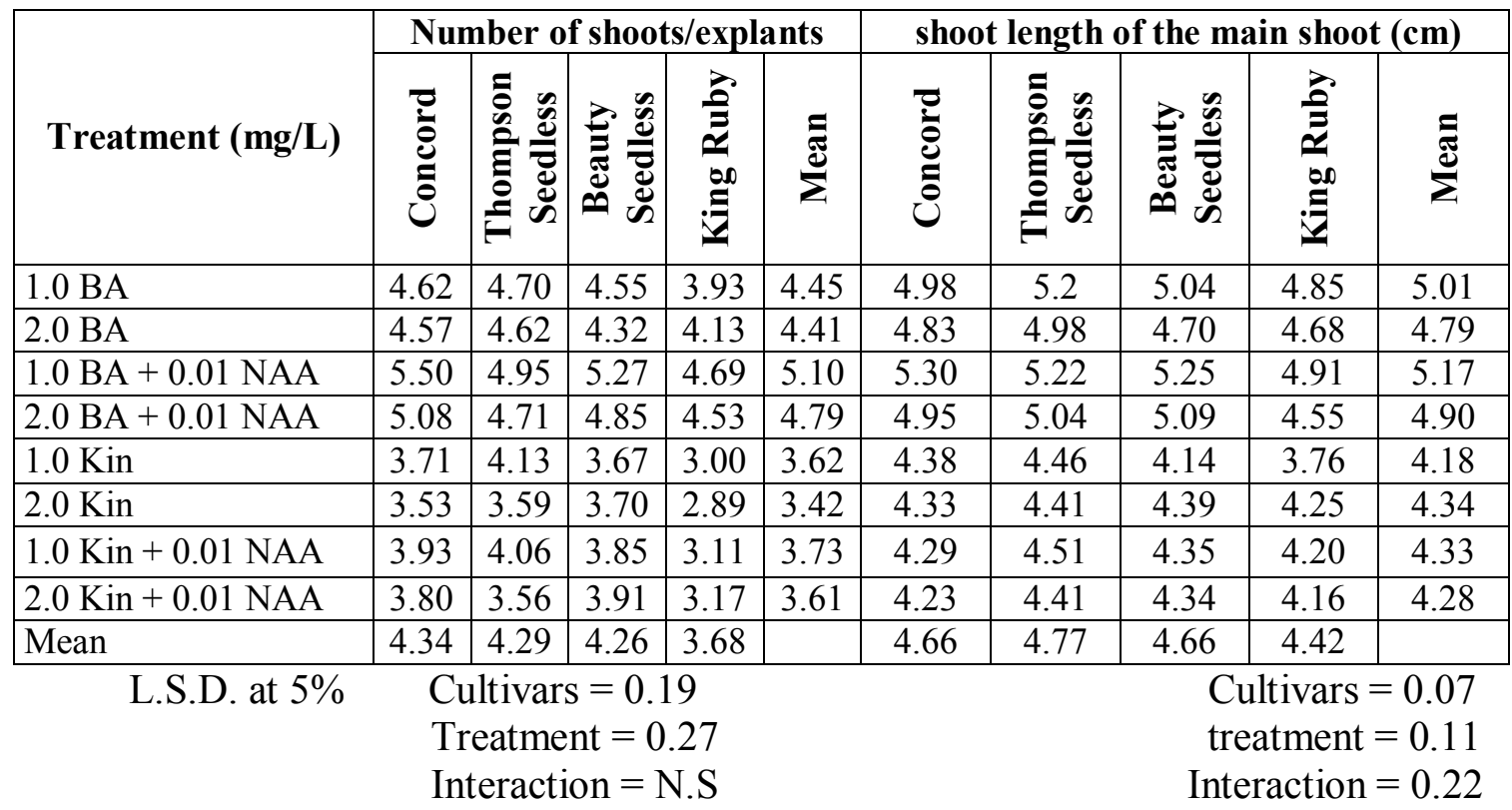

\section{Multiplication of shoots:}

In order to determine the optimum number of subculture to obtain the best cultures without affecting multiplication rate, propagation was continued by culturing explants for five cycles on fresh culture medium containing the same composition as shown in table (4). Data revealed that for all genotypes tested the maximum subcultures that did not affect the sprouting rate was the third subculture. The sprouting percentage was $100,100,100$ and $87.5 \%$ for Con- 
cord, Thompson Seedless, Beauty Seedless and King Ruby, respectively,. In the fourth subculture the sprouting rate was decreased to 91.6 , 66.6, 75 and $66.6 \%$ for Concord, Thompson Seedless, Beauty Seedless and King Ruby, respectively. The decrease was found to be significant for Thompson Seedless and Beauty Seedless cultivars. Moreover, in the third subculture, the highest mean number of shoots/ explants 6.52, $6.38,5.96$ and 5.79 were obtained from Concord, Thompson Seedless, Beauty Seedless and King Ruby, respectively,. Concord produced the highest significant mean number of shoots/explants compared to Beauty Seedless and King Ruby cultivars, while the difference between Concord and Thompson Seedless was not significant. Several authors indicated that the third subculture was the most suitable for cultures (Ibanez et al., 2003). High propagation rates with high concentrations of cytokinins were reported to increase the possibility of somaclonal variation (Silvestroni 1981; Mukherjee et al., 2010). Near to our result, Torregrosa and Bouquet (1995) reported that above three subcultures reduction in propagation frequency with the formation of vitrified shoots were observed. Increase the number of subculters of Refosk genotype was reported to have negative influence on shoot elongation (Koruza and Jelaska 1993). In contrast to our results, (Alizadeh et al., 2010) found the gradual increase in the multiplication rates was documented with elevated cycles till the eight subculture for different rootstocks.

Table (4): Effect of subsequent subcultures on sprouting rate (\%) and number of shoots/explants of four grape cultivars

\begin{tabular}{|c|c|c|c|c|c|c|c|c|c|c|}
\hline \multirow[b]{2}{*}{$\begin{array}{l}\text { Sub- } \\
\text { culture }\end{array}$} & \multicolumn{5}{|c|}{ Sprouting rate (\%) } & \multicolumn{5}{|c|}{ Number of shoots/ explants } \\
\hline & $\begin{array}{l}\overline{0} \\
\dot{0} \\
\tilde{0}\end{array}$ & 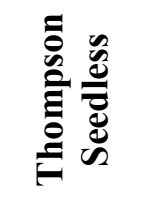 & 龸若 & 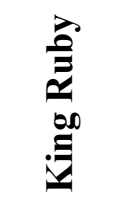 & $\sum_{\Sigma}^{\Xi \Xi}$ & 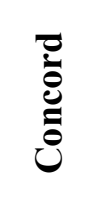 & 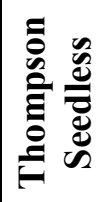 & 党总 & 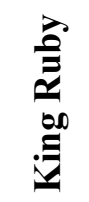 & $\sum_{\Sigma}^{\mathbb{E}}$ \\
\hline $1^{\text {st }}$ & 100.00 & 91.60 & 100.00 & 83.30 & 95.87 & 5.50 & 5.30 & 5.05 & 5.17 & 5.25 \\
\hline $2^{\text {nd }}$ & 100.00 & 100.00 & 100.00 & 91.60 & 97.9 & 6.29 & 6.10 & 5.79 & 5.37 & 5.88 \\
\hline $3^{\text {rd }}$ & 100.00 & 100.00 & 100.00 & 87.50 & 96.87 & 6.52 & 6.38 & 5.96 & 5.79 & 6.16 \\
\hline $4^{\text {th }}$ & 91.60 & 66.60 & 75.00 & 66.60 & 74.95 & 5.91 & 5.75 & 5.22 & 4.83 & 5.42 \\
\hline $5^{\text {th }}$ & 87.50 & 58.30 & 62.50 & 50.00 & 64.57 & 3.67 & 3.83 & 3.15 & 3.88 & 3.63 \\
\hline Mean & 95.83 & 83.13 & 87.50 & 75.81 & & 5.58 & 5.47 & 5.03 & 5.01 & \\
\hline & L.S.D. & $\begin{array}{l}\mathrm{Su} \\
\text { Int }\end{array}$ & $\begin{array}{l}\text { ltivars = } \\
\text { culture = } \\
\text { raction = }\end{array}$ & $\begin{array}{l}0.10 \\
0.11 \\
\text { N.S }\end{array}$ & & & $\begin{array}{l}\text { Cultiva } \\
\text { Subcul } \\
\text { Interac }\end{array}$ & $\begin{array}{l}\text { ss }=0 \\
\text { ure }= \\
\text { ion }=1\end{array}$ & & \\
\hline
\end{tabular}

\section{Rooting of shoots:}

Although, shoots of in vitro grapes could spontaneously rooting without hormones (Lu 2005; Khan et al.; 2015), the supplementation of auxins on rooting medium positively enhanced rooting capability (Lawandowski 1991; Compoton and Gray 1994). IBA has been the most widely used auxin in grape tissue cul- 
ture for rooting purpose (Helior et al., 1997; Hicks and Dorey 1998; Jaskani et al., 2008). Data in table [5] demonstrated the effect of different IBA concentrations with half and full strength of MS medium on rooting percentage and the mean number of roots/explant. Rooting of in vitro shoots was occurred on all tested media with the different concentrations of IBA. R1 (1/2 strength of MS medium containing $1.0 \mathrm{mg} / \mathrm{L}$ IBA) and R2 medium (1/2 strength of MS medium containing $2.0 \mathrm{mg} / \mathrm{L} \mathrm{BA}$ ) significantly produced the best rooting capacity and the highest root numbers/explant. R1 recorded the rooting percentage $(90,100,80$ and $70 \%)$ with the optimum average of root numbers/explants $(4.4,6.1,4.6$ and 3.86) for Concord, Thompson seedless, Beauty seedless and King Ruby, respectively,. While R2 achieved the rooting percentage $(90,90,70$ and $70 \%$ ) with the maximum average of root numbers/explants (4.11, 5.33, 4.14 and 4.0) for Concord, Thompson seedless, Beauty seedless and King Ruby, respectively. There was a de- crease in root frequency correlated by the increase of IBA level in both half and full strength of MS. These results disagree with (Tehrim et al., 2013) who found linear relationship between rooting rate and IBA concentrations. Half strength of MS medium was observed to be more valuable for root induction than full strength of MS. This might be due to the lower concentration of nitrogen in half strength MS which slower the vegetative growth and promote the growth of roots. Beura (2003) documented that half strength MS medium supplied with IBA $0.5-1.0 \mathrm{mg} / \mathrm{L}$ was the best for in vitro rooting for most horticulture crops. These findings regard the strong role of IBA on rooting formation were in agreement with Zhang et al. (2006); Jaskani et al. (2008)., While, Mukherjee et al. (2010) found that in comparison between three auxin types ( IAA, IBA and NAA), IAA $(0.2 \mathrm{mg} / \mathrm{L})$ promoted the best rooting $(84 \%)$, whereas, NAA or IBA increased the callus formation of grape. 
Table (5): Effect of different concentrations of IBA combined with different concentrations of MS medium on rooting percentage (\%) and number of roots/explants in four grape cultivars.

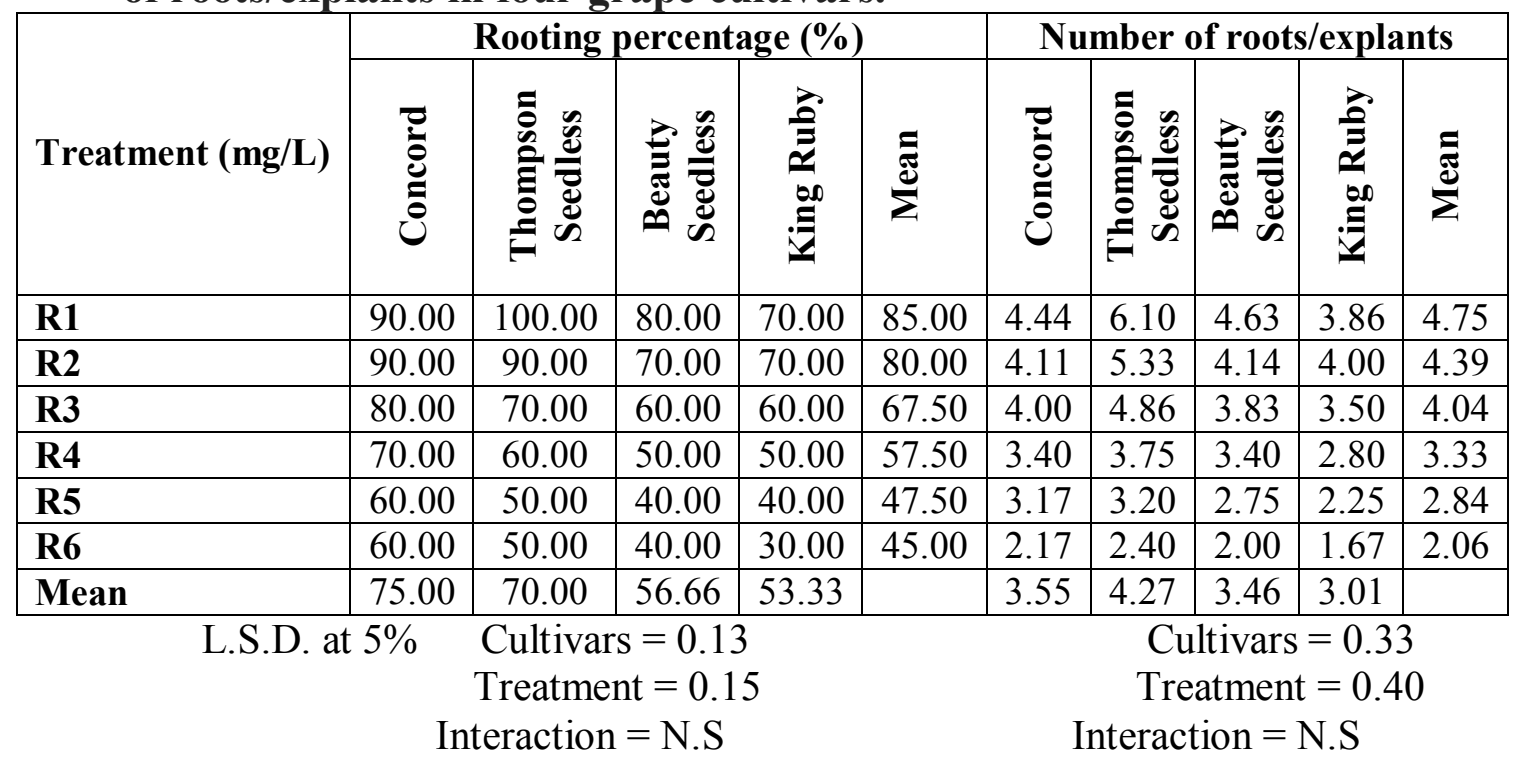

\section{References:}

Aazami, M.A. (2010). Effect of some growth regulators on "in vitro" culture of two Vitis vinifera L. cultivars. Rom. Bot. Let, 15(3): 5229-5232.

Alizadeh, M.; Singh, S.K.; and Patel, V.B. (2010). Comparative performance of in vitro multiplication in four grape (Vitis spp.) rootstock genotypes. International Journal of Plant Production 4(1): 41-50.

Beura, S. (2003). Micro-propagation and its use for improvement of Horticulture crops. In Advanced in propagation method for production of quality planting material of tropical and subtropical horticultural crops (Bhubnesshwar). pp: 102-107.

Bouquet, A. and Torregrosa, L. (2003). Micropropagation of the grapevine (Vitis spp.). In Micropropagation of woody trees and fruits (pp. 319-352). Springer Netherlands.
Compton, M. E., and Gray, D. J. (1994). Micro-propagation of 'Southern Home' hybrid grape. Electrophoresis 24: 128-130.

Dzazio, P.M.; Biasi, L.A. and Zanette, F. (2002). Micropropagation of '420-A' grapevine rootstock. Revista Brasileira de Fruticultura 24(3): 759-764.

El-Agamy, S.Z.; El-Mahdy, T.K. and Mohamed, A.A. (2008). In vitro propagation of some grape rootstocks. Acta Hortic. 839: 125131.

Gomez, K.A. and Gomez, A.A. (1984). Statistical procedures for agricultural research. 2nd Ed., John Willy, NY, 680 pp.

Gordon, M.E.; Letham, D.S. and Beever, J. (1975). Regulators of cell division in plant tissues. Physiologia Plantarum, 35(1): 27-33.

Heloir, M.C.; Fournioux, J.C.; Oziol, L. and Bessis, R. (1997). An improved procedure for the propagation in vitro of grape- 
vine (Vitis vinifera cv. Pinot noir) using axillary bud microcuttings. Plant Cell Tissue Org. Cult. 49: 223-225.

Hicks, G.S. and Dorey, M. (1998). Shoot multiplication growth and adventitious rooting in 3 cultivars of Vitis, in vitro. Proc. Nova Scotian Inst. Sci., 38: 8389.

Hu, C.Y. and Wang, P.J. (1983). Meristem, shoot tip and bud cultures, pp. 177-227. In: Handbook of plant cell culture, Vol. 1 Techniques for propagation and breeding: Evans D.A., Sharp W.R., Ammirato P.V. and Yamada Y. (Eds.), Macmillan, New York.

Ibáñez, A.; Valero, M. and Morte, A. (2003). Influence of cytokinins and sub-culturing on proliferation capacity of single-axillarybud microcuttings of Vitis vinifera L. cv. Napoleón. An. Biol 25: 81-90.

Jamwal, M.; Singh, B.; Sharma, N.; Kumar, R.; Sharma, A.; Sharma, R.M. and Parmar, A.M. (2013). In vitro regeneration of grape (Vitis vinifera L.) cv. Perlette. World Journal of Agricultural Sciences, 9(2): 161-166.

Jaskani, M.J.; Abbas, H.; Sultana, R.; Khan, M.M.; Qasim, M. and Khan, I.A. (2008). Effect of growth hormones on micropropagation of Vitis vinifera $\mathrm{L}$. cv. Perlette. Pakistan Journal of Botany 40(1):105-109.

Khan, N.; Ahmed, M.; Hafiz, I.; Abbasi, N.; Ejaz, S. and Anjum, M. (2015).Optimizing the concentrations of plant growth regulators for in vitro shoot cul- tures, callus induction and shoot regeneration from calluses of grapes. Journal international des sciences de la vigne et du vin 49(1): 37-45.

Koruza, B. and Jelaska, S. (1993). Influence of meristem culture and virus elimination on phenotypical modifications of grapevine (Vitis vinifera L. cv. Refosk). Vitis 32: 59-60.

Lewandowski, V.T. (1991). Rooting and Acclimatization of Micropropagated Vitis labrusca Delaware'. HortScience 26(5): 586-589.

Lu, M.C. (2005). Micropropagation of Vitis thunbergii Sieb. et Zucc., a medicinal herb, through high-frequency shoot tip culture. Scientia Horticulturae 107(1): 64-69.

Mhartte, M.; C.K. Salunke and P.S. Rao, (2000). Micro-propagation of Vitis vinifera L: towards an improved protocol. Sci. Hortic. 84: 357-363.

Mukherjee, P.; Husain, N.; Misra, S.C. and Rao, V.S. (2010). In vitro propagation of a grape rootstock, deGrasset (Vitis champinii Planch.): Effects of medium compositions and plant growth regulators. Scientia horticulturae 126(1): 13-19.

Murashige, T. and Skoog, F. (1962). A revised medium for rapid growth and bio assays with tobacco tissue cultures. Physiologia Plantarum 15(3): 473-497.

Nookaraju, A., Barreto, M.S. and Agrawal, D.C. (2008). Rapid in vitro propagation of grapevine cv. Crimson Seedless-influence of basal media and plant growth 
regulators. J Appl Hort 10: 4449.

Poudel, P.R.; Kataoka, I. and Mochioka, R. (2005). Effect of plant growth regulators on in vitro propagation of Vitis ficifolia var. ganebu and its interspecific hybrid grape. Asian Journal of Plant Sciences, 4: 466-71.

Sajid, G.M.; Ilyas, M.K. and Anwar, R. (2006). Effect of diverse hormonal regimes on in vitro growth of grape germplasm. Pakistan Journal of Botany 38(2): 385.

Silvestroni, O. (1981). Prime esperienze sulla micropropagazione della vite europea. Vignevini 8 (10): 31-37.

Tapia, M.I. and Read, P.E. (1998). Propagation of grape hybrids by in vitro culture of axillary buds.
Agro. Ciencia 14 (1): 35-41. (C.F. Hort. Abst. 69(6): 4834).

Tehrim, S.; Mirza, M.Y. and Sajid, G.M. (2013). Comparative study of different growth regulators for efficient plant regeneration in grapes. Pakistan Journal of Agricultural Research (Pakistan) 26 (4): 275-289.

Torregrosa, L. and Bouquet, A. (1995). In vitro propagation of Vitis x Muscadinia hybrids by microcuttings or axillary budding. Vitis 34(4): 237-238.

Zhang, J.L.; Xu, R.; Cao, Z.Y.; Wang, S.M. and Ren, J.Z. (2006). Factors affecting in vitro propagation of a Chinese wild grape (Vitis piasezkii var. pagnucii): Shoot production and rhizogenesis. New Zealand journal of crop and horticultural science 34(3): 217-223. 


\section{إكثار أربعة أصناف من العنب معمليا}

فاروق محمد احمد مصطفى ، مختار ممدوح شعبان ، دعاء شحاتة العزب ، مروة طلعت كامل

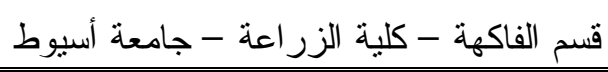

أجريت هذه الدر اسة لإكثار أربعة أصناف من العنب معمليا وهى الكونكورد ، طومسسون

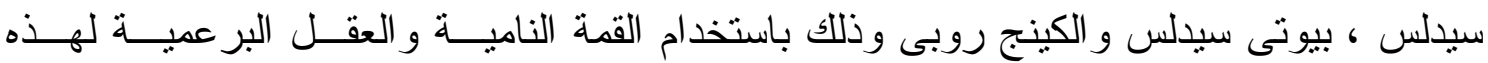

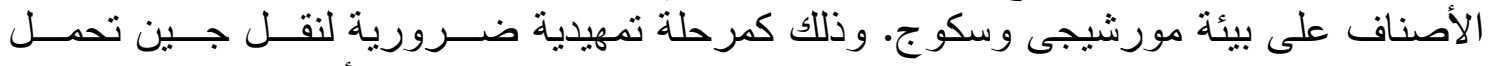

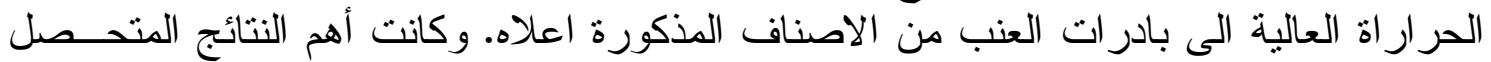

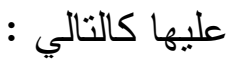

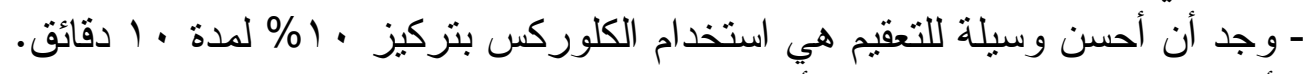

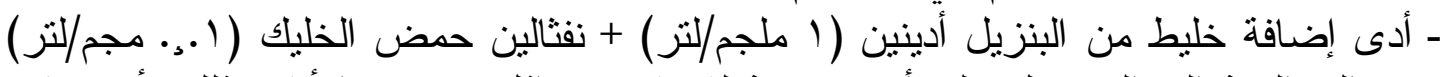

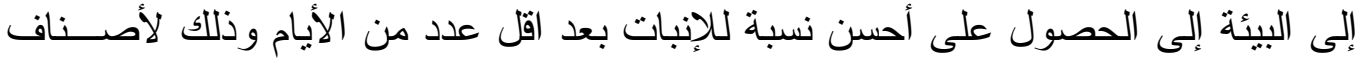

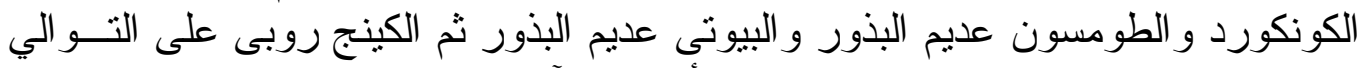

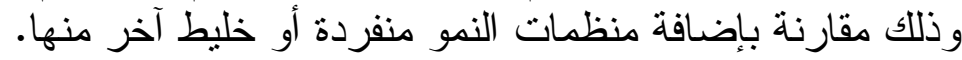
ـ أدى استخدام البيئة المذكورة إلى الحصول على أعلى عدد من الأفرع الجانبية وكذلك طول هذه الأفرع.

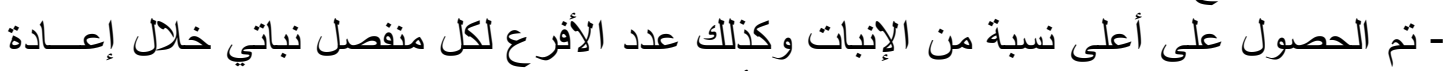

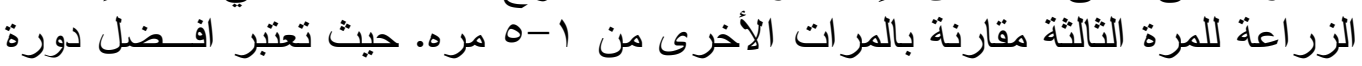

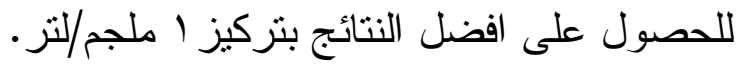
- إضافة ا ملجم/لتز من أندول حمض البيوتريك إلى بيئة نصف التهن التركيز مور اثنيجى وسكوج

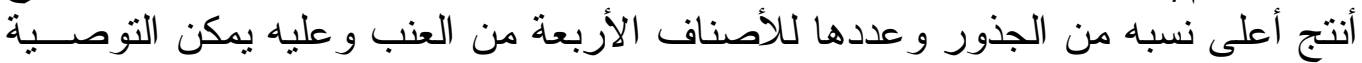

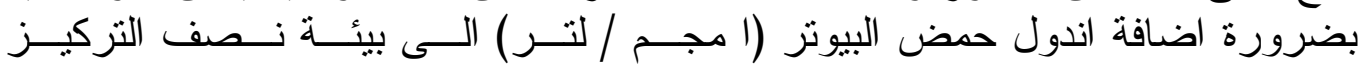

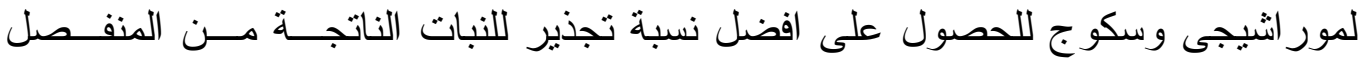
النباتى لاحدى اصناف العنب المختبرة تحت ظروف لاف هذة الدر اسة. 